\title{
The Perception of Medium Scale Entrepreneurs on Credit Decision Making
}

\section{Christian Herdinata}

\author{
International Business Management Program, School of Business, Universitas Ciputra, Indonesia
} christian.herdinata@ciputra.ac.id

\section{Doi:10.5901/mjss.2016.v7n1p11}

\begin{abstract}
The use of credit as a funding source must be based on careful planning and decision making, especially for medium scale entrepreneurs. Incorrect use of credit may cause problems for medium scale entrepreneurs. Therefore, the acts of medium scale entrepreneurs in using credit as a funding source are closely related to their perception of the benefits and risks of the credit obtained from financial institutions. Consequently, this research aims to reveal the perception of medium scale entrepreneurs in utilizing credit as a funding source. This research uses 74 respondents as samples, which consist of medium scale entrepreneurs in Surabaya, Indonesia. This research is categorized as a qualitative descriptive research. The data were obtained through questionnaires distributed to medium scale entrepreneurs who used credit as a funding source in running their business. The result of this research suggests that the highest average value indicates that medium scale entrepreneurs perceive credit as a stimulus to act carefully in managing and using their money. This research also concludes that education and business experience as demographic factors hold significant values towards credit as stimulus. Likewise, age and business experience as demographic factors are also perceived to have significant values on credit as burden.
\end{abstract}

Keywords: Perception, Medium scale entrepreneurs, Credit decision,Financial institution

\section{Introduction}

Micro, Small and Medium Entreprises (MSMEs) are the backbone of Indonesia's economic development. Based on Indonesia's population of around 210 million people, approximately 80,933,384 people rely on a variety of micro, small and medium enterprises (Kompas, February 29, 2007). It is true that MSME has several flaws, such as the lack of legal entities, income instability, technology simplicity, and the use of family members as labours. However, despite these flaws, more attention and support should be given to develop MSME into sustainable enterprises (Hastuti, 2003).

One of the most important internal problem which remains difficult to overcome is funding source limitation (Darmawan, 2005). Credit is a funding source alternative for MSME entrepreneurs. Supramono and Putlia (2010) revealed that only a few enterprises used credit as a funding source, either from banks or other financial institutions. This fact underlines the significance of examining funding sources, particularly credit.

The use of credit as a funding source must be based on careful planning and decision making, especially for micro, small and medium scale entrepreneurs. Incorrect use of credit may instead lead to problems for these entrepreneurs. Credit-based funding source can be obtained from financial institutions, including banks and other institutions. Based on the research result of the Ministry of Cooperatives and SMEs and the Central Bureau of Statistics (2003), only 17.5\% entrepreneurs used banks to get additional capital. Therefore, it can be said that the decision of micro, small and medium scale entrepreneurs to use credit as a funding source is closely related to their perception of the benefits and risks generated by the credit.

The right understanding of the decision to use credit as a funding source for consumption and production needs affects the entrepreneur's ability to repay the debt. Problems arise when the loanee fails to repay the credit in time. Therefore, this research aims to project the perception of medium scale entrepreneurs on the use of credit as a funding source. The benefits of this research are: (1) to provide medium scale entrepreneurs with the right perception of credit decision making; (2) to supply banks with the knowledge of how medium scale entrepreneurs perceive credit decision making; (3) to support academicians with broader theoretical analysis on the perception of entrepreneurs on credit decision making; and (4) to help readers and the general public understand the perception of medium scale entrepreneurs on credit decision making. 


\section{Literature Review}

\subsection{The Perception of Credit Decision Making}

The perception of credit as a funding source is analyzed using behavioural finance approach, which emphasizes the odd and irrational behaviours of a person when making money-related decisions because psychological factors are more influential than other factors (Hirschey and Nofsinger, 2008). Credit can be perceived as both positive and negative. Statman (1995), Kahnemandan Riepe (1998), and Kircher, Maciejovcky, and Weber (2005) have conducted tests which suggest that the tendency of providing either positive or negative information affects the outcome of the decision making. Since credit is considered as a stimulus in business development, it provides entrepreneurs with the support needed to obtain profit through working capital. On the other hand, credit is also considered as a burden for the development of a business, because the interest rates and the installments pile more pressure on the entrepreneurs and the business they manage (Supramono and Putlia, 2010).

\subsection{Credit Management Planning}

Credit management planning is a way to manage loan, from the time it is given to the time it is paid off. For micro, small and medium enterprises (MSME), a guideline for credit management is needed. Credit can be used to enhance or protect cash flow or finance growth or expansion. Respatiningsih (2011) pointed out at several considerations of getting a loan, including: (1) improving work force or increasing supply using working capital; (2) expanding market share when entering a new market; (3) buying new equipments and expanding product lines; (4) increasing cash flow; and (5) building trust with lenders.

\subsubsection{Effective and Efficient Credit Planning}

Planning capital requirement is essential to determine the amount of loan and the type of funding sources. It also enables micro, small and medium enterprises (MSME) to predict cash needs and determine what is required and when it is required. It is also helpful in selecting loan source options and conducting negotiations using favorable terms (Respatiningsih, 2011). Therefore, planning requires financial position report to analyze cash flow, assets, and liabilities. Additionally, it also requires financial position report projection for the next one to three years.

\subsubsection{Time Frame of Credit Utilization}

The use of credit demands micro, small and medium scale entrepreneurs to pay due installments. This becomes a problem with the high amount of installments a loanee must pay over a given period, especially when the loanee experiences money shortage. Therefore, in general, short-term loan is meant for short-term needs and long-term loan for long-term needs. This will help micro, small and medium scale entrepreneurs avoid higher and stricter interest rate. Credit time frame will not affect debt to equity ratio. However, it influences liquidity indicators such as current ratio, because it includes credit obligation that should be repaid within a certain period of time (Respatiningsih, 2011).

\subsubsection{Credit Utilization Based on Needs}

When interest rate is low, entrepreneurs tend to take up loans (Respatiningsih, 2011). It is interesting to examine whether such wish is in line with the needs of the business. Therefore, micro, small and medium scale entrepreneurs must maintain proper credit management. A failure to do so may lead to massive debt and bad credit. According to Respatiningsih (2011), two things must be taken into consideration; the amount of monthly installment and the credit repayment based on financial position.

\subsection{The Perception of Credit as Stimulus and Burden}

Past research studies have examined the influence of psychological factors on investment and funding decisions. Among the said studies are The Demographics of Overconfidence (Bhandari and Daves, 2006), Managerial Overoptimism and the Choice between Debt and Equity Financing (Gombola and Marciukaityte, 2007), Ambiguity Aversion and Illuison of Control (Grou and Tabak, 2008), and Illusion of Control Source of Poor Diverfication (Fellner, 2009). Arguably, the 
number of studies on the subject of credit as stimulus and burden as perceived by entrepreneurs is relatively small. Supramono and Putlia (2010) stated that credit can be perceived positively as a stimulus for business development. On the other hand, it can also have a negative perception when the entrepreneurs think that the credit becomes a burden for the development of their business. Credit can serve as a stimulus by encouraging entrepreneurs to provide added values for the development of their business. On the contrary, credit can also be a burden if it prevents entrepreneurs from giving added values to their business development. This matter is important because it affects the decision making regarding credit utilization.

\section{Research Methods}

The samples of this research are medium scale entrepreneurs with the focus on medium scale enterprises in Surabaya, Indonesia. Data were obtained through questionnaire and interviews with 74 respondents, which consisted of medium scale entrepreneurs in Surabaya with active businesses. Data collection was based on the answers obtained from the questionnaires given to the micro, small and medium scale entrepreneurs with the focus on medium scale enterprises in Surabaya, Indonesia. The research of Supramono and Putlia (2010) is used as a reference to determine the indicators of the perception of credit as stimulus and burden in credit decision making. This research uses descriptive qualitative approach to analyze the data. The result of the questionnaires is analyzed using classified mean score for further examination and discussion purposes. This research also uses chi-square test to determine the correlation between demographic factors and the indicators of credit perception as stimulus and burden with less than 0.05 significance value.

\section{Data Analysis Result}

Below is the data analysis result based on the findings obtained from the 74 respondents who are medium scale entrepreneurs in Surabaya, Indonesia to determine the perception in credit management decisions:

Table 1. Profile of Respondents Based on Gender

\begin{tabular}{cccc}
\hline & Gender & Amount & $\%$ \\
\hline A & Male & 39 & $52.70 \%$ \\
B & Female & 35 & $47.30 \%$ \\
\hline & Total & 74 & $100.00 \%$ \\
\hline
\end{tabular}

Source: processed data

Table 1 suggests that the numbers of female and male respondents in this research are relatively equal with $52.70 \%$ male and $47.30 \%$ female.

Table 2. Profile of Respondents Based on Age

\begin{tabular}{|c|c|c|c|}
\hline & Age & Amount & $\%$ \\
\hline $\bar{A}$ & 17 - 27 years & 16 & $21.62 \%$ \\
\hline B & 28 - 37 years & 15 & $20.27 \%$ \\
\hline C & 38 - 47 years & 17 & $22.97 \%$ \\
\hline D & $48-57$ years & 23 & $31.08 \%$ \\
\hline \multirow[t]{2}{*}{$E$} & $>57$ years & 3 & $4.05 \%$ \\
\hline & Total & 74 & $100.00 \%$ \\
\hline
\end{tabular}

Source: processed data

Table 2 indicates that the average age range of the medium scale entrepreneurs is between $48-57$ years with the percentage of $31.08 \%$. It can also be seen from this table that the percentage for the $17-27$ years age range reaches $21.62 \%$. This suggests the relatively young age of entrepreneurs who run their own businesses. It also indicates the amount of trust given to these relatively young entrepreneurs to run medium scale businesses. 
Table 3. Profile of Respondents Based on Business Experience

\begin{tabular}{cccc}
\hline & Business Experience & Amount & $\%$ \\
\hline A & Yes & 55 & $74.32 \%$ \\
B & No & 19 & $25.68 \%$ \\
\hline & Total & 74 & $100.00 \%$ \\
\hline
\end{tabular}

Source: processed data

The data in Table 3 indicate that the majority of the medium scale entrepreneurs had had some business experience by the time they ran the current business. This fact suggests that business experience is a factor that business owners consider in running a business. It also implies that business experience can act as a supporting factor in the successful management of the business in the future.

Table 4. Profile of Respondents Based on Funding Source

\begin{tabular}{cccc}
\hline & Funding Source Priority & Amount & $\%$ \\
\hline A & Credit & 35 & $47.30 \%$ \\
B & Personal capital & 37 & $50.00 \%$ \\
C & Profit & 2 & $2.70 \%$ \\
\hline & Total & 74 & $100.00 \%$ \\
\hline
\end{tabular}

Source: processed data

Table 4 shows that the business funding source priority of the medium scale entrepreneurs is still dominated by personal capital with $50 \%$, followed by credit as the other alternative with $47.30 \%$. These figures confirm credit as the second priority after personal capital for business funding source.

Table 5. Indicators of the Perception of Credit as Stimulus and Burden

\begin{tabular}{lcccc}
\hline Credit Perception Indicator & Min & Max & Avg & Std. Dev \\
\hline Panel A. Stimulus & & & & \\
Financial support & 1 & 5 & 3.72 & 0.712 \\
Discipline and productivity & 1 & 5 & 3.74 & 0.760 \\
Credit benefit is bigger than risk & 1 & 5 & 3.42 & 0.907 \\
Trustworthiness & 1 & 5 & 3.36 & 0.930 \\
Cautiousness in money management & 2 & 5 & 4.12 & 0.548 \\
Panel B. Burden & & & & \\
Interest rates aggravate business finance & 2 & 5 & 3.80 & 0.758 \\
More pressure and less freedom in using income & 2 & 5 & 3.74 & 0.703 \\
Poor business performance & 2 & 5 & 2.97 & 0.776 \\
Psychological burden of sluggish market & 2 & 5 & 3.99 & 0.652 \\
Uncertainty in future funding & 2 & 5 & 3.39 & 0.718 \\
\hline
\end{tabular}

Source: processed data

The data in Table 5 suggest that the indicator for credit perception as a stimulus with the highest average value is the perception of credit as a stimulus for cautiousness in money management with an average of 4.12 . This shows that credit has encouraged medium scale entrepreneurs to be careful in their money management by separating business and family finances and paying installments regularly. Additionally, the indicator for credit perception as burden with the highest average value is the perception of credit as a psychological burden when the market is sluggish with an average of 3.99. This suggests that credit has given entrepreneurs psychological burden over the concerns of declining market condition. This concern is normal, considering that the entrepreneurs have the obligation to pay due credit principal along with the interest. 
The chi-square test results on the demographic factors with the indicator of the perception of credit as stimulus can be seen in Table 6. As one of the indicators of demographic factors, education shows a significance value of 0.004 towards credit perception in the context of credit benefit which is bigger than risk. This suggests that high education level provides medium scale entrepreneurs with good understanding on the role of credit as a way to obtain capital for business management. Another indicator of demographic factors, which is business experience, shows a significance value of 0.098 towards the perception of credit in terms of discipline and productivity; 0.019 for credit benefit which is bigger than risk; and 0.010 for trustworthiness. These numbers suggest that business experience encourages medium scale entrepreneurs to have good understanding on how to be productive and disciplined, understand productive management of risk so that the benefit of credit is bigger than the risk, and show consistency and commitment in settling due payments in order to gain trust from others through credit.

Table 6. Chi-square Test Results of Demographic Factors and the Perception of Credit as Stimulus

\begin{tabular}{|l|c|c|c|c|c|}
\hline Stimulus & $\begin{array}{c}\text { Financial } \\
\text { support }\end{array}$ & $\begin{array}{c}\text { Discipline and } \\
\text { productivity }\end{array}$ & $\begin{array}{c}\text { Credit benefit is } \\
\text { bigger than risk }\end{array}$ & Trustworthiness & $\begin{array}{c}\text { Cautiousness in } \\
\text { money management }\end{array}$ \\
\hline Education & 0.867 & 0.625 & $0.004^{*}$ & 0.153 & 0.332 \\
\hline Age & 0.207 & 0.048 & 0.272 & 0.102 & 0.708 \\
\hline Business Experience & 0.397 & $0.098^{\star \star}$ & $0.019^{*}$ & $0.010^{\star *}$ & 0.948 \\
\hline
\end{tabular}
Note: * sig. $0.05 ;{ }^{*}$ sig. 0.1

Source: processed data

The chi-square test results on the demographic factors with the indicator of the perception of credit as burden can be seen in Table 7. As one of the indicators of demographic factors, age shows a significance value of 0.004 towards the perception of credit in terms of interest rate burden; 0.015 in terms of poor performance; and 0.005 in terms of funding uncertainty. This suggests that the age difference between entrepreneurs is related to the perception of credit as burden in terms of interest rate burden, poor performance and funding uncertainty. This is very common for relatively young entrepreneurs whose lack of business experience prevent them from having a good understanding on the role of credit in managing a business. As another indicator of demographic factors, business experience shows a significance value of 0.031 towards the perception of credit in terms of interest rate burden and 0.062 in terms of funding uncertainty. The numbers suggest that the business experience of an entrepreneur is related to the condition of credit as burden, particularly in terms of interest rate burden and funding uncertainty. This condition applies mostly to entrepreneurs with minimum business experience, in which credit is seen as a burden due to interest rate burden and funding uncertainty.

Table 7. Chi-square Test Results of Demographic Factors and the Perception of Credit as Burden

\begin{tabular}{|l|c|c|c|c|c|}
\hline Burden & Interest rate burden & Pressure & Poor performance & Psychological burden & Funding uncertainty \\
\hline Education & 0.124 & 0.329 & 0.190 & 0.833 & 0.710 \\
\hline Age & $0.004^{*}$ & 0.341 & $0.015^{\star}$ & 0.170 & $0.005^{\star}$ \\
\hline Business Experience & $0.031^{*}$ & 0.424 & 0.189 & 0.085 & $0.062^{\star \star}$ \\
\hline
\end{tabular}

Note: * sig. 0.05; *夫 sig. 0.1

Source: processed data

\section{Discussion}

Credit can be perceived as positive or negative. The positive perception of credit is a supporting factor in funding alternative. The data in Table 4 suggest that credit is the second alternative after personal capital for medium scale entrepreneurs. This shows that medium scale entrepreneurs consider credit as an effective funding source in running a business. Additionally, the average age range of $48-57$ years suggests that age factor and experience factor are complementary.

The intriguing part of this research is the indicator for credit perception as burden with the highest average value is the perception of credit as a psychological burden when the market is sluggish with an average of 3.99. As a result, entrepreneurs are challenged to develop the right marketing strategy in terms of product, promotion, place and pricing. It 
is also equally important to execute the right segmentation, targeting and positioning for the current business to benefit from a constantly increasing annual profit. This idea is in line with the opinion of Champion (1999) who stated that credit was one of the strategies for companies to improve their performances. Furthermore, this statement is supported by the findings stated in Table 5, which suggest that the lowest average value perceived by medium scale entrepreneurs is 2.97. It shows that entrepreneurs have come to realize that credit can improve business performance.

Based on the classification of psychological factors described by Shefrin (2007), which includes overconfidence, illusion of control and availability, the findings of this research discover that the most dominant factor in the credit decision making of medium scale entrepreneurs is overconfidence. Bhandari and Deaves (2006) argued that most people tended to be overconfident by showing the tendency to be confidently certain of the knowledge, ability and information accuracy they possessed. According to the data on credit as a stimulus in Table 5, it can be concluded that the credit decision making for medium scale entrepreneurs can make them productive and disciplined. It suggests that the entrepreneurs are confident of their ability to repay the credit and the interest within the designated time period. This confidence is based on their belief that they will be able to utilize their credit well and that their business performance will continue to grow. This is indicated by the second highest average value of 3.74. Consequently, a productive and disciplined entrepreneur tends to be very confident in taking high-risk credit, while at the same time, taking into account the value of the potential benefits.

The chi-square test results on demographic factors with the indicator of the perception of credit as stimulus, as explained in Table 6, suggest that high education level provides medium scale entrepreneurs with good understanding on the role of credit as a way to obtain capital for business management. Additionally, business experience encourages medium scale entrepreneurs to have good understanding on how to be productive and disciplined, understand productive management of risk so that the benefit of credit is bigger than the risk, and show consistency and commitment in settling due payments in order to gain trust from others through credit. This conclusion is in line with the opinion of Champion (1999) who described credit as one of the means used by companies to increase performance. The chi-square test results on demographic factors with the indicator of the perception of credit as burden, as seen in Table 7, suggest that entrepreneurs with relatively young age and minimum business experience often perceive credit as a burden due to the interest rate burden and funding uncertainty. This conclusion is supported by Gibson (2007) who described the complex relationship between funding sources that come from personal capital and credit, particularly for micro and small individually-owned companies. This statement is based on the suggestion that the owner's assets are used as credit collateral. As a result, business owners face the risk of uncertain returns.

\section{Conclusions and Recommendations}

The conclusions of this research concerning the perception of medium scale entrepreneurs in Surabaya, Indonesia regarding credit decision making are as follows: (1) the majority of the medium scale entrepreneurs have had previous experience before running the current business. It shows that business experience is a factor that these entrepreneurs consider in running a business; (2) the funding source priority of the medium scale entrepreneurs is still dominated by personal capital with $50 \%$, followed by credit as the second alternative with $47.30 \%$. This shows that credit is considered as the second priority after personal capital in terms of business funding source; (3) the indicator for credit perception as a stimulus with the highest average value is the perception of credit as a stimulus for cautiousness in money management with an average of 4.12. Additionally, the indicator for credit perception as burden with the highest average value is the perception of credit as a psychological burden when the market is sluggish with an average of 3.99. This shows that credit has encouraged medium scale entrepreneurs to be careful in their money management by separating business and family finances and paying installments regularly. Moreover, medium scale entrepreneurs need to ensure proper marketing efforts in terms of product, promotion, place and pricing. In addition to that, special attention must also be given to the segmentation, targeting and positioning of the business in order to reduce the psychological burden over a sluggish market; (4) education and business experience as demographic factors have significant values on credit as stimulus. Likewise, age and business experience as demographic factors also hold significant values towards credit as burden. A suggestion for medium scale entrepreneurs is to use credit as a funding alternative to increase business performance. Finally, financial institutions can use the findings of this research as a reference to offer credit to medium scale entrepreneurs. 


\section{References}

Bhandari, G. R. \& Deaves. 2006. The Demographics of Overconfidence. The Journal of Behavioral Finance, Vol.7, pp. 5-11.

Champion, D. 1999. Finance: The Joy of Leverage. Harvard Business Review, Vol.77, pp.19-22.

Darmawan. (2005). Faktor-Faktor yang Dapat Menentukan Keberhasilan Usaha Industri Mikro, Kecil, dan Menengah Sektor Karajinan di Kotamadya Yogyakarta.[The Factors Affecting the Success of Micro, Small and Medium Craft Enterprises in Yogyakarta].Tesis. Pascasarjana Universitas Indonesia

Fellner, G. 2009. Illusion of Control as a Source of Poor Diversification: Experimental Evidence. Journal of Behavioral Finance, Vol.10, pp.55-67.

Gibson. (2007). Accounting Standars and Small Firm Debt and Equity: An International Research Agenda. Australia: Murdoch Business School.

Gombola, M. \& Marciukaityte, D. 2007. Managerial Overoptimism and the Choice Between Debt and Equity Financing. Journal of Behavioral Finance, Vol.8, pp.225-235.

Grou, B. \& Tabak, B.M. 2008. Ambiguity Aversion and Illusion of Control: Experimental Evidence in an Emerging Market. Journal of Behavioral Finance, Vol.9, pp.22-29.

Hastuti. (2003). Upaya Penguatan Usaha Mikro Dalam Rangka Peningkatan Ekonomi Perempuan. [Efforts to Strengthen Micro Business in Order to Increase the Economy for Women] (Sukabumi, Bantul, Kebumen, Padang, Surabaya, Makassar). Jakarta, Indonesia: Lembaga Penelitian Smeru.

Hirschey, D \& Nofsinger, J. (2008). Invesments: Analysis and Behavior. Boston : Mc-Graw-Hill, Irwin.

Kahneman, D \& Riepe, M.W. (1998). Aspect of Investor Psychology. Journal of Portfolio Management, Vol. 24, pp. 52-65.

State Ministry of Cooperatives and SMEs and Central Bureau of Statistics. (2003).

Kircher, E., Maciejovcky, \& Weber, M.F. (2005). Effect, Selective Information, and Market Behavior: An Experimental Analysis. The Journal of Behavioral Finance, Vol.6, pp.90-100.

Kompas. (29 February 2007). Usaha Mikro Kecil dan Menengah di Indonesia. [Micro, Small

and Medium Enterprises in Indonesia].

Respatiningsih, Hesti. (2011). Manajemen Kredit Usaha Mikro Kecil dan Menengah (UMKM) [Credit Management of Micro,Small and Medium Enterprises (MSME)]. Segmen Jurnal Manajemen dan Bisnis, No 1, Januari.

Shefrin, H. 2007. Behavioral Corporate Finance: Decisions that Create Value. McGraw-Hill//Irwin

Statman. (1995). A Behavioral Framework for Dollar-Cost Averaging. Journal of Portofolio Management, Vol. 22, pp.70-78.

Supramono \& Putlia, N. (2010). Persepsi dan Faktor Psikologis Dalam Pengambilan Keputusan Utang.[The Perception and Psychological Factor of Credit Decision Making].Jurnal keuangan dan Perbankan, Vol 1 Januari, hal 24-35. 